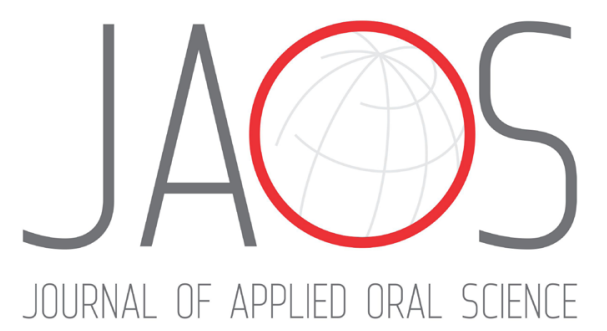

\title{
How pathological criteria can impact prognosis of tongue and floor of the mouth squamous cell carcinoma
}

\section{Abstract}

Renata Miranda RODRIGUES ${ }^{1}$

Vagner Gonçalves BERNARDO ${ }^{2}$

Sabrina Daniela DA SILVA ${ }^{3}$

Danielle Resende CAMISASCA ${ }^{4}$

Paulo Antônio de Silvestre FARIA ${ }^{5}$

Fernando Luiz DIAS ${ }^{6}$

Luís Felipe Ribeiro PINTO ${ }^{7}$

Rodolpho Mattos ALBANO²

Anke BERGMANN ${ }^{7}$

Simone de Queiroz Chaves

LOURENÇO ${ }^{1}$ iD
Pathological parameters have been indicated as tumor prognostic factors in oral carcinoma. Objective: The objective of this study was to investigate the impact of pathological parameters on prognosis of patients affected only by tongue and/or floor of the mouth squamous cell carcinoma (SCC). Methodology: In total, 380 patients treated in the Brazilian National Cancer Institute (INCA) from 1999 to 2006 were included. These patients underwent radical resection followed by neck dissection. The clinical and pathological characteristics were recorded. The Kaplan-Meier method and Cox proportional hazards model were used in survival analysis. Overall survival (OS), cancer-specific survival (CSS) and disease-free interval (DFI) were estimated. Cox residuals were evaluated using the $\mathrm{R}$ software version 3.5.2. Worst OS, CSS and DFI were observed in patients with tumors in advanced pathological stages $(p<0.001)$, with the presence of perineural invasion $(p<0.001)$ and vascular invasion $(p=0.005)$. Results: Advanced pathological stage and the presence of a poorly differentiated tumor were independent prognostic factors for OS and CSS. However, advanced pathological stage and perineural invasion were independent predictors of a shorter OS, DFI and CSS. Conclusion: Pathological stage and perineural invasion were the most significant pathological variables in survival analysis in tongue and/or floor of the mouth SCC.

Keywords: Oral cancer. Squamous cell carcinoma. Prognosis. Survival. Oral pathology.
Submitted: March 28, 2019 Modification: May 22, 2019

Accepted: May 30, 2019
'Universidade Federal Fluminense, Programa de Graduação em Odontologia, Niterói, Rio de Janeiro, Brasil. de Janeiro, Brasil.

${ }^{3}$ Segal Cancer Centre, Department of Otolaryngology, Head and Neck Surgery; Sir Mortimer B. DavisJewish General Hospital, Lady Davis Institute for Medical Research, Montréal, Canada.

${ }^{4}$ Universidade Federal do Espírito Santo, Departamento de Patologia Oral, Vitória, Espírito Santo, Brasil.

${ }^{5}$ Instituto Nacional de Câncer (INCA), Divisão de Patologia, Rio de Janeiro, Rio de Janeiro, Brasil. ${ }^{6}$ Instituto Nacional de Câncer (INCA), Departamento de Cirurgia de Cabeça e Pescoço, Rio de Janeiro, Rio de Janeiro, Brasil.

${ }^{7}$ Instituto Nacional de Câncer (INCA), Centro de Pesquisas, Programa de Carcinogênese Molecular. 


\section{Introduction}

Head and neck cancer is the sixth most common type of cancer, ${ }^{1}$ being strongly associated with tobacco and alcohol consumption. Several regions, including the oral cavity, can be affected by these tumors. Squamous cell carcinomas (SCC) are the most common type of tumor in this region. Oral cancer is usually caused by epithelial lining cell transformation. The incidence of 354,864 new cases for both sexes was expected worldwide in $2018 .{ }^{1}$ When compared to other South American countries, Brazil presented the highest rates of oral cancer. ${ }^{2}$ Data from the Brazilian National Cancer Institute (INCA) estimated that oral cancer was the fifth most common type of cancer among men and the $12^{\text {th }}$ among women in $2018 .^{3}$

Tongue is the most commonly affected site in oral cavity, followed by the floor of the mouth. ${ }^{4}$ Studies show that tumors on this site have a worse prognosis than other sites in the oral cavity due to their incomplete response to treatment strategies, resulting in lower survival rates. ${ }^{5}$ Consequently, cancer of the oral cavity has higher mortality rates (50\%) when compared to other types of cancer. ${ }^{1}$

The TNM classification is used clinically to define therapy and estimate its response and prognosis. ${ }^{6}$ However, it does not necessarily reflect a precise impact on prognosis. Tumors associated with the same stage of this classification can show different disease progression. ${ }^{7-8}$ New parameters such as depth of invasion and extracapsular extravasation, were included in the $8^{\text {th }}$ edition of TNM (2017) to improve their predictive value and different stages stratification, and to reorganize patients previously considered low risk but had a shorter survival.

The pathological parameters described as tumor prognostic indicators in oral SCC are: pathological stage, histopathological grading of the World Health Organization (WHO), ${ }^{9}$ presence of vascular and perineural invasion, extracapsular spread and positive surgical margins. ${ }^{9-12}$

Therefore, this study sought to investigate the impact of pathological parameters on the prognosis of patients with tumors in tongue and floor of the mouth SCC only, and treated primarily by radical surgery in a single institution (INCA).

\section{Methodology}

\section{Study population}

Data from 380 patients with oral SCC diagnosed between 1999 and 2006 were extracted from a database of the Department of Head and Neck Surgery (Process \#125/10 - INCA ethics committee). The tumors of these patients affected only oral tongue and the floor of the mouth. The exclusion criteria were: being a second primary cancer, presence of distant metastasis at the time of diagnosis and with a follow-up that lasted less than one month. All patients underwent radical resection as initial treatment and had surgical margins free of tumor, confirmed either with frozen section or with final pathological examination. The first treatment for the primary carcinoma also included neck dissection. In total, 204 patients received postoperative therapy (radiotherapy). Chemotherapy was not indicated for any patient.

\section{Data collection}

All medical records and pathologic reports were reviewed and the data were collected as shown in Table 1. Pathological data included tumor stage (pTNM). The $7^{\text {th }}$ edition of TNM Classification of Malignant Tumors (UICC staging system) was used to classify the tumors as either early (I/II) or advanced (III/IV), ${ }^{13}$ the presence of vascular permeation and perineural invasion, and tumor differentiation, according to the WHO grading system. ${ }^{9}$

\section{Statistical analysis}

For descriptive and statistical analysis, the SPSS statistics package for Windows (version 20.0, IBM Corp., Armonk, NY, USA) was used. Analysis of survival was estimated using surgery date as starting point. The overall survival (OS), cancer-specific survival (CSS) and disease-free interval (DFI) were estimated using the Kaplan-Meier method and log-rank test for curve comparison. To evaluate prognostic factors associated with pathological parameters, hazard ratios (HR) were estimated with 95\% confidence intervals (95\%CI). The Cox proportional hazards model was used in each group after controlling for potentially confounding variables. Cox residuals were evaluated using the $\mathrm{R}$ software version 3.5.2. The tests were considered statistically significant when the p-value was $<0.05$. 


\section{Results}

All the 380 patients of a single institution received the same protocol procedures for diagnosis and treatment. Tumor-derived specimens had the same histological type (squamous cell carcinoma) and site (tongue and floor of the mouth). The profile of the studied population followed REMARK's recommendations. ${ }^{14,15}$

\section{Clinicopathological results}

Clinical and pathological characteristics are presented in Table 1. In total, 380 patients, 292 males (76.8\%) and 88 females $(23.2 \%)$, with 57 years as the median age were enrolled in this study (range 20-93 years). Most cases were tongue SCCs ( $n=210$, $55.3 \%$ ). In total, 78 tumors (20.5\%) were floor of the mouth SCCs and 92 tumors (24.2\%) affected both sites, simultaneously. Most patients showed clinical stage II $(n=160 ; 42.1 \%)$, followed by stage III ( $n=99$; $26.1 \%)$. Pathologic staging was: stage IV $(n=122$; $32.1 \%)$; stage II $(n=99 ; 26.1 \%)$; stage III $(n=82$; $21.6 \%)$ and stage I ( $n=77 ; 20.3 \%)$. Lymph node (LN) neck dissection was performed in all patients (259 unilateral lymph node dissections and 121 bilateral lymph node dissections). Pathological lymph node metastasis ( $\mathrm{pN}$ ) was detected in 174 patients (45.8\%). Surgical treatment was indicated as the only treatment for 176 patients $(46.4 \%)$.

The median follow-up period was 4.3 years (range $0.2-10$ years). The overall recurrence rate was $42.6 \%(n=150)$ including local recurrences, cervical metastases and distant metastases. A second primary tumor was found in 59 cases (15.5\%). Clinical and pathological characteristics are presented in Table 1.

\section{Survival analysis}

The 10-year OS, CSS and DFI rates were $55.3 \%$, $33.2 \%$ and $40.8 \%$, respectively. Kaplan-Meier curves revealed that patients with advanced pathologic stage tumors (III and IV) showed worse OS (95\%CI 46.559.4; $\mathrm{p}<0.001)$, CSS (95\%CI 62.2-77.3; p<0.001) and DFI (95\%CI 44.2-59.1; $\mathrm{p}=0.002$ ) (Figure 1A, B, C). Tumors with perineural invasion showed worse OS (95\%CI $40.2-59.2 ; p<0.001)$, CSS $(95 \% \mathrm{CI}$ 54.8-77.5; $\mathrm{p}<0.001)$ and DFI (95\%CI 33.0-54.3; $\mathrm{p}<0.001$ ) (Figure 1D, E, F).

Poorly differentiated tumors (WHO system) had prognostic value for both OS $(p=0.03)$ and CSS $(p=0.009)$ (Figure 2). Significantly, lower DFI values were observed in the presence of perineural and vascular invasion and pathological stage III/IV (Table 2).

Table 1- Clinicopathological features of the samples $(n=380)$

\begin{tabular}{|c|c|c|c|}
\hline Variable & Category & $\begin{array}{l}\text { No. of } \\
\text { cases }\end{array}$ & $\begin{array}{l}\% \text { of } \\
\text { cases }\end{array}$ \\
\hline \multirow[t]{2}{*}{ Gender } & Male & 292 & 76.8 \\
\hline & Female & 88 & 23.2 \\
\hline \multirow[t]{3}{*}{ Age } & $<40$ years & 28 & 7.4 \\
\hline & $\geq 40<65$ years & 255 & 67.1 \\
\hline & $\geq 65$ years & 97 & 25.5 \\
\hline \multirow[t]{3}{*}{ Tobacco } & No & 56 & 14.7 \\
\hline & Current or Past & 322 & 84.7 \\
\hline & Not recorded & 2 & 0.6 \\
\hline \multirow[t]{3}{*}{ Alcohol } & No & 73 & 19.2 \\
\hline & Current or Past & 304 & 80.0 \\
\hline & Not recorded & 3 & 0.8 \\
\hline \multirow[t]{3}{*}{ Tumor site } & Tongue & 210 & 55.3 \\
\hline & Floor of mouth & 78 & 20.5 \\
\hline & Both & 92 & 24.2 \\
\hline \multirow[t]{4}{*}{ Clinical stage } & 1 & 84 & 22.1 \\
\hline & II & 160 & 42.1 \\
\hline & III & 99 & 26.1 \\
\hline & IV & 37 & 9.7 \\
\hline \multirow[t]{4}{*}{ Pathological stage } & I & 77 & 20.3 \\
\hline & II & 99 & 26.1 \\
\hline & III & 82 & 21.6 \\
\hline & IV & 122 & 32.0 \\
\hline \multirow[t]{2}{*}{$\mathrm{pN}$} & No & 206 & 54.2 \\
\hline & $\mathrm{N} 1+2$ & 174 & 45.8 \\
\hline \multirow[t]{4}{*}{ Grading } & Well & 67 & 17.6 \\
\hline & Moderately & 288 & 75.8 \\
\hline & Poorly & 18 & 4.7 \\
\hline & Not recorded & 7 & 1.9 \\
\hline \multirow[t]{2}{*}{ Perineural invasion } & No & 293 & 77.1 \\
\hline & Yes & 87 & 22.9 \\
\hline \multirow[t]{2}{*}{ Vascular invasion } & No & 332 & 87.4 \\
\hline & Yes & 48 & 12.6 \\
\hline \multirow[t]{2}{*}{ Extracapsular spread } & No & 354 & 93.2 \\
\hline & Yes & 26 & 6.8 \\
\hline \multirow[t]{2}{*}{ Adjuvant treatment } & No & 176 & 46.3 \\
\hline & Yes & 204 & 53.7 \\
\hline \multirow[t]{2}{*}{ Disease progression } & No & 309 & 81.3 \\
\hline & Yes & 71 & 18.7 \\
\hline \multirow[t]{2}{*}{ Second primary tumor } & No & 321 & 84.5 \\
\hline & Yes & 59 & 15.5 \\
\hline
\end{tabular}




\section{Multivariate Cox regression analysis}

The variables were analyzed by the Kaplan-Meier method (univariate analysis) and, when p-values were $\leq 0.20$, they were included in the Cox regression model for multivariate analysis (log-rank test). Multivariate analysis showed pathological stage III/IV $(\mathrm{HR}=2.1$; 95\%CI 1.60-2.87; $p<0.001$ ) and perineural invasion $(\mathrm{HR}=1.47 ; 95 \% \mathrm{CI} 1.08-1.99 ; \mathrm{p}=0.01)$ as independent factors for a lower OS (Table 3).

Likewise, pathological stage III/IV $(H R=2.72$; 95\%CI 1.81-4.09; $p<0.001)$, perineural invasion $(\mathrm{HR}=1.57 ; 95 \% \mathrm{CI} 1.06-2.31 ; \mathrm{p}=0.02)$ and poorly differentiated tumors $(\mathrm{HR}=2.00 ; 95 \% \mathrm{CI} 1.07-3.73$; $p=0.03$ ) were significant for CSS.

The independent predictive factor for a lower DFI was pathological stage III/IV (HR=1.64; 95\%CI $1.22-$ $2.21 ; \mathrm{p}<0.001)$ and perineural invasion $(\mathrm{HR}=1.58$; 95\%CI 1.15-2.16; $p=0.004$ ) (Table 3).
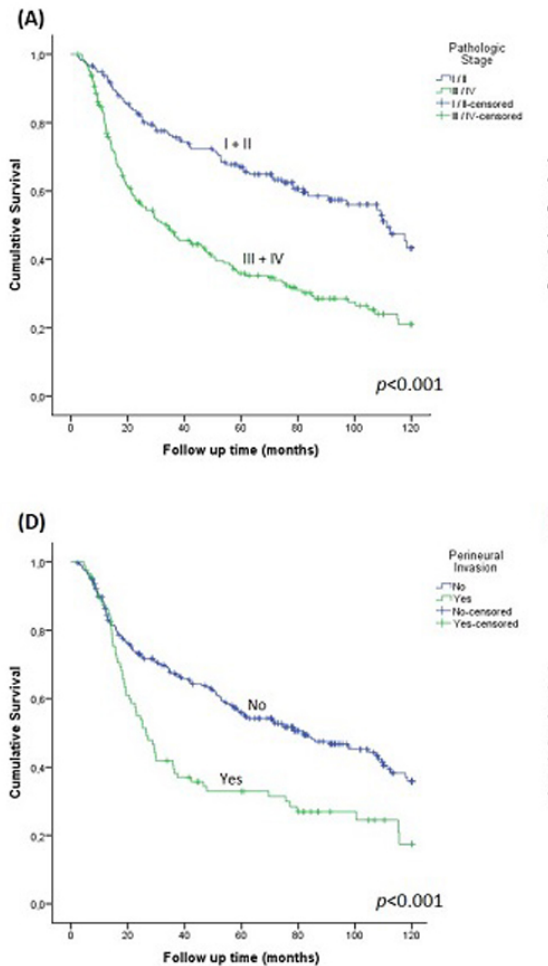

(B)

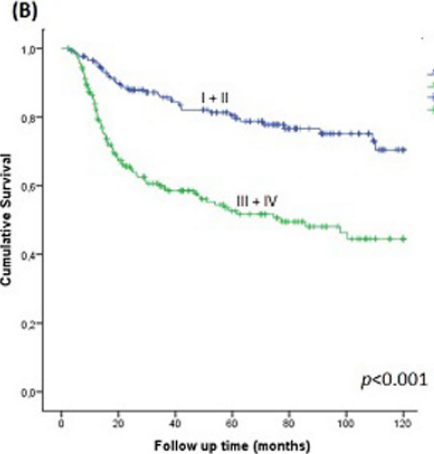

(E)

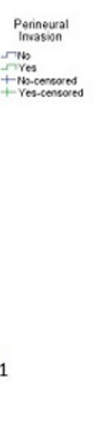

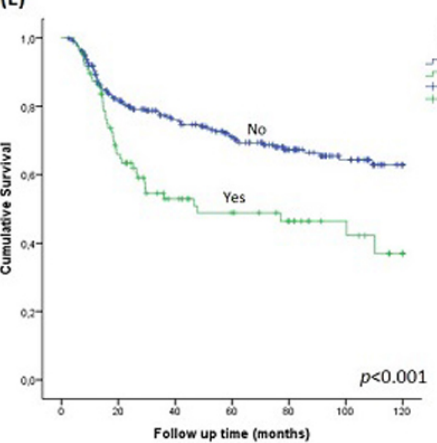

(c)
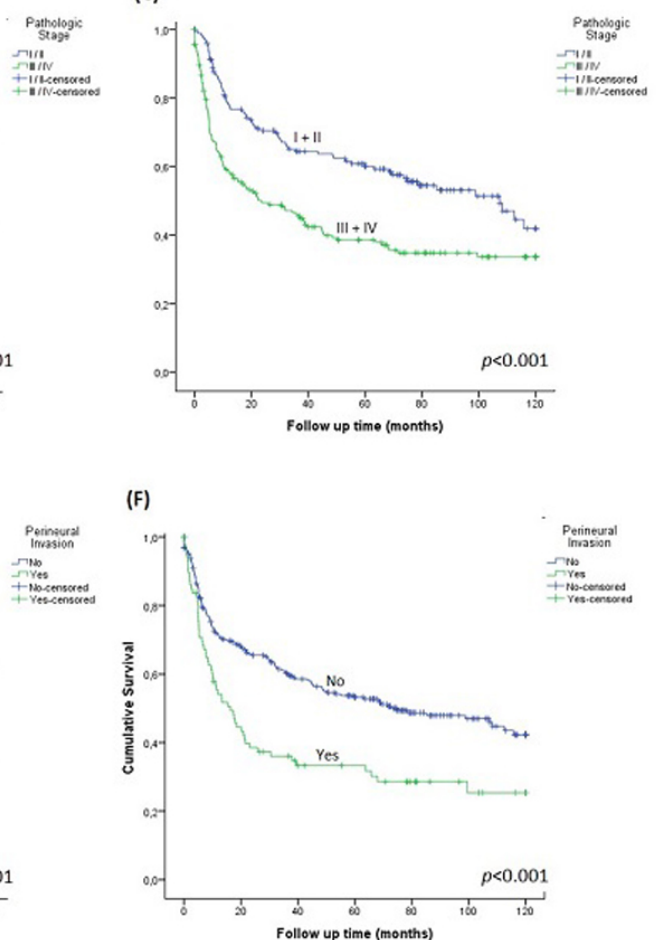

(F)

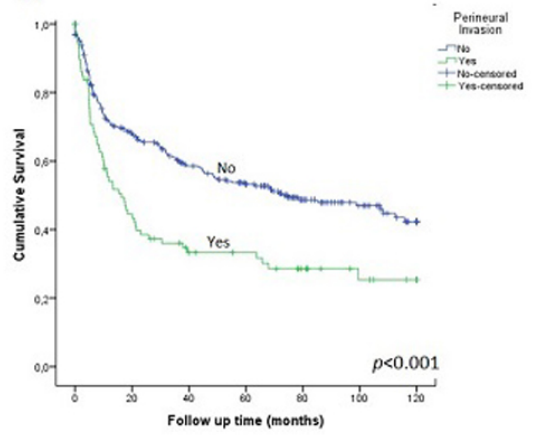

Figure 1- Survival charts of pathological stages. A- Overall (OS); B- Cancer-specific survival (CSS); C- Disease-free interval (DFI) and perineural invasion; D- OS; E- CSS; F- DFI

(A)

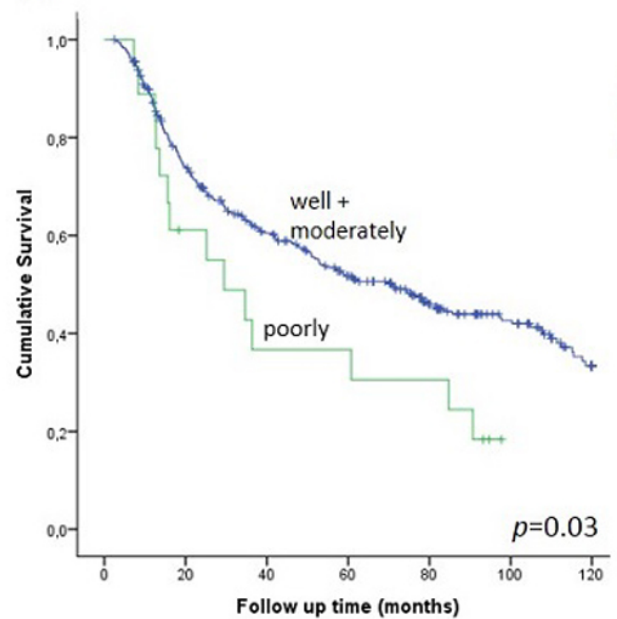

(B)

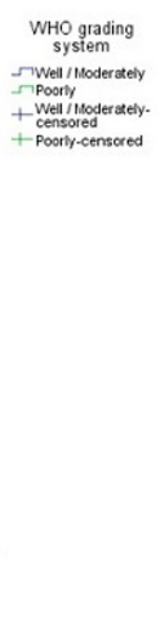

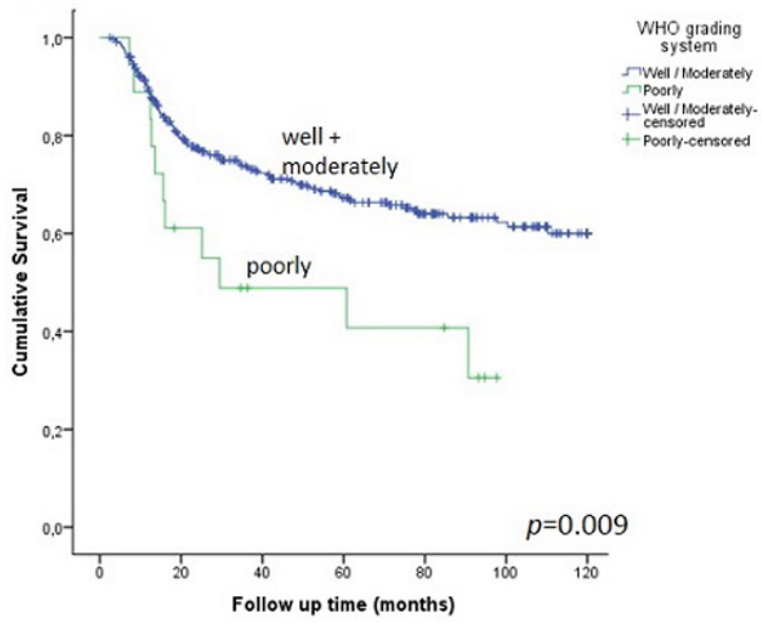

Figure 2- Survival charts of WHO grading system. A- Overall (OS); B- Cancer-specific survival (CSS) 
Table 2- Pathological characteristics and survival: univariate analysis

\begin{tabular}{|c|c|c|c|c|c|c|c|}
\hline \multirow[b]{2}{*}{ Variable } & \multirow[b]{2}{*}{$\begin{array}{c}\text { No. } \\
\text { of } \\
\text { cases }\end{array}$} & \multicolumn{2}{|c|}{ Overall survival } & \multicolumn{2}{|c|}{ Cancer-specific survival } & \multicolumn{2}{|c|}{ Disease-free interval } \\
\hline & & $(95 \% \mathrm{Cl})$ & $p$ value & $(95 \% \mathrm{Cl})$ & $p$ value & $(95 \% \mathrm{Cl})$ & $p$ value \\
\hline \multicolumn{8}{|c|}{ Pathological Stage } \\
\hline $\mathrm{I} / \mathrm{II}$ & 176 & $(76.7-90.2)$ & & $(92.2-104.6)$ & & $(66.9-82.4)$ & \\
\hline III/IV & 204 & $(46.5-59.4)$ & $<0.001$ & $(62.2-77.3)$ & $<0.001$ & $(44.2-59.1)$ & $<0.001$ \\
\hline \multicolumn{8}{|l|}{ Grading system } \\
\hline Well/ Moderately & 355 & $(63.7-73.9)$ & & $(80.1-90.6)$ & & $(57.3-68.7)$ & \\
\hline Poorly & 18 & $(28.3-61.2)$ & 0.03 & $(33.8-70.4)$ & 0.009 & $(21.9-71.3)$ & 0.23 \\
\hline \multicolumn{8}{|c|}{ Perineural invasion } \\
\hline Yes & 87 & $(40.2-59.2)$ & & $(54.8-77.5)$ & & $(33.0-54.3)$ & \\
\hline No & 293 & $(67.1-78.2)$ & $<0.001$ & $(82.9-94.1)$ & $<0.001$ & $(61.9-74.4)$ & $<0.001$ \\
\hline \multicolumn{8}{|l|}{ Vascular invasion } \\
\hline Yes & 48 & $(33.4-56.8)$ & & $(46.9-76.2)$ & & $(30.7-58.5)$ & \\
\hline No & 332 & $(65.5-76.0)$ & $<0.001$ & $(81.2-92.0)$ & $<0.001$ & $(59.3-71.1)$ & 0.005 \\
\hline \multicolumn{8}{|c|}{ Extracapsular spread } \\
\hline Yes & 26 & $(62.0-99.8)$ & & $(81.6-115.4)$ & & $(51.6-92.4)$ & \\
\hline No & 354 & $(61.0-71.1)$ & 0.09 & $(76.8-87.5)$ & 0.10 & $(55.9-67.3)$ & 0.32 \\
\hline
\end{tabular}

Table 3- Multiple regression Cox analysis for the factors influencing overall, cancer-specific and disease-free interval

\begin{tabular}{|c|c|c|c|c|c|c|c|}
\hline \multirow[t]{2}{*}{ Variable } & \multirow[t]{2}{*}{ Category } & \multicolumn{2}{|c|}{ Overall survival } & \multicolumn{2}{|c|}{ Cancer-specific survival } & \multicolumn{2}{|c|}{ Disease-free interval } \\
\hline & & HR (95\% Cl) & p Value & HR (95\% Cl) & p Value & $\mathrm{HR}(95 \% \mathrm{Cl})$ & p Value \\
\hline Pathological Stage & I+II/ III+IV & $2.14(1.60-2.87)$ & $<0.001$ & $2.72(1.81-4.09)$ & $<0.001$ & $1.64(1.22-2.21)$ & $<0.001$ \\
\hline Perineural invasion & Yes/ No & $1.47(1.08-1.99)$ & 0.01 & $1.57(1.06-2.31)$ & 0.02 & $1.58(1.15-2.16)$ & 0.004 \\
\hline Grading system & $\begin{array}{c}\text { Well+ } \\
\text { Moderately/ Poorly }\end{array}$ & a & a & $2.0(1.07-3.73)$ & 0.03 & a & a \\
\hline
\end{tabular}

a. Variable not included in the analysis

\section{Discussion}

Oral SCC remains as one of the most difficult malignancies to control due to its high tendency for local invasion and cervical lymph node dissemination, especially the tongue and floor of the mouth SCC. ${ }^{16,17}$ This is the reason why its survival rates remain low, even with advances in therapeutic strategies. ${ }^{18}$ The prediction of tumor behavior is difficult when using only conventional clinical and histological parameters. ${ }^{19}$

Several studies include reliable pathological parameters in oral tumor staging to improve the prognosis. ${ }^{7-20,21}$ Some studies investigated the prognostic role of pathologic parameters in oral SCC, in general, analyzing the parameters separately. ${ }^{11-24}$ On the other hand, our study comprised most of the pathological criteria, including pathological stage, WHO grading system, perineural infiltration and vascular invasion.

The $8^{\text {th }}$ edition of TNM Classification of Malignant
Tumours, proposed in 2017, 12 is a strong independent predictor factor of both OS and CSS for SCC in tongue and floor of the mouth. By including extracapsular extension and depth of invasion as critical prognostic factors for SCC of the oral cavity, it may effectively measure the risk associated with pathological variables. Thus, an increase in the depth of invasion probably precedes and influences perineural and perivascular invasions. In addition, perineural invasion and WHO grading system could be included in TNM classification for a more complete variable, because these are the most predictable variables, as suggested by Subramaniam, et al. ${ }^{25}$ (2019), using the new edition of TNM, and also our study, using the $7^{\text {th }}$ edition.

We were unable to assess the depth of invasion in our study due to only using medical records. Also, this study was carried out before the publication of the new edition of the TNM Classification of Malignant Tumours. ${ }^{12}$ Therefore, we are planning to include these new parameters in the studied population. 
Moreover, we selected, according to our inclusion criteria, patients considered free surgical margins. Positive margins can significantly decrease overall survival and increase the risk of local recurrence. ${ }^{9,26}$

Furthermore, our data suggest that pathological TNM staging is an important prognostic factor due to its ability to predict not only OS and CSS, but also DFI. In addition, this variable predicts both OS and CSS independently. Amit, et al. ${ }^{27}$ (2018) showed the same results, with a significant association with OS and CSS in multivariate analysis for pathological TNM stage.

Our study confirms that perineural invasion is a predictor of unfavorable DFI, which was already observed in a previous study with the same criteria. ${ }^{24}$ Perineural invasion was also a predictor of worst OS and CSS and showed an independent prognostic value in multivariate analysis. Vascular invasion has been significantly associated with survival ${ }^{11}$, but our study also showed it as a significant prognostic indicator for OS, CSS and DFI.

Also, our data showed poor differentiated tumors as an independent predictor for CSS. WHO grading system was a predictor of worst CSS in multivariate analysis, thus emerging as an important pathologic parameter. Poorly differentiated tumors presented higher recurrence rates and showed a shorter cancer specific survival when compared to well and moderately differentiated tumors. Although some authors did not prove its independent prognostic value, ${ }^{28,29}$ other authors had the same conclusion, as reported by Lindenblatt, et al. ${ }^{30}$ (2012) and Sopka, et al. ${ }^{31}$ (2013). These conclusions reflect that the biology of undifferentiated tumors is usually associated with increased mitotic activity and invasiveness. We propose further studies of this variable to confirm our findings, and perhaps allow its inclusion in the TNM Classification.

As limitations of this study we point the use of secondary sources, such as histopathological reports and medical records, and the unavailability of some information. Histopathological reports were performed by different pathologists from the same institution. We suggest an additional study including tumors in other sites to complement our observations. However, our findings reinforce the need to describe all pathologic parameters in histopathological reports.

\section{Conclusion}

In conclusion, pathological criteria have direct impact in patient's prognosis. In addition, an independent predictor of survival was found for PTNM, perineural invasion and WHO grading system. Our study highlights the fact that the WHO grading system is also a promising prognostic indicator for tongue and floor of the mouth SCC.

\section{Conflict of interest disclosures}

The authors declare no conflicts of interest.

\section{Acknowledgements}

This study was supported by Coordination of Higher Education and Graduate Training (CAPES) and Ministry of Health (INCA).

\section{References}

1- Ferlay J, Colombet M, Soerjomataram I, Mathers C, Parkin DM, Piñeros $M$, et al. Estimating the global cancer incidence and mortality in 2018: GLOBOCAN sources and methods. Int J Cancer. 2019;144(8):1941-53. 2- Curado MP, Johnson NW, Kerr AR, Mendonça e Silva DR, Lafranchi $H$, Pereira $D L$, et al. Oral and oropharynx cancer in South America: incidence, mortality trends and gaps in public databases as presented to the Global Oral Cancer Forum. Transl Res Oral Oncol. 2016;1:1-7 doi: $10.1177 / 2057178 \times 16653761$.

3- Brasil. Ministério da Saúde. Instituto Nacional de Câncer José de Alencar Gomes da Silva [online]. Estimativa 2018. [cited 2019 March 28]. Available from: http://www.inca.gov.br/estimativa/.

4- Barasch A, Morse DE, Krutchkoff DJ, Eisenberg E. Smoking, gender, and age as risk factors for site-specific intraoral squamous cell carcinoma. A case-series analysis. Cancer. 1994:73(3):509-13. 5- Ord RA. Surgical management of the NO neck in early stage T1-2 oral cancer; a personal perspective of early and late impalpable disease. Oral Maxillofac Surg. 2012:16(2):181-8.

6- Brandwein-Gensler M, Teixeira MS, Lewis CM, Lee B, Rolnitzky J], Hille J, et al. Oral squamous cell carcinoma: histologic risk assessment, but not margin status, is strongly predictive of local disease-free and overall survival. Am J Surg Pathol. 2005:29(2):167-78

7- Bettendorf O, Piffkò J, Bànkfalvi A. Prognostic and predictive factors in oral squamous cell cancer: important tools for planning individual therapy? Oral Oncol. 2004:40(2):110-9

8- Hubert TH, Gao K, Elliott M, Clark JR. Tumor classification for early oral cancer: re-evaluate the current TNM classification. Head Neck. 2015:37(2):223-8.

9- El-Naggar AK, Chan JK, Grandis JR, Takata T, Slootweg PJ. World Health Organization classification of head and neck tumours. Pathology and genetics of head and neck tumors. Lyon: IARC Press; 2017. 10- Brandwein-Gensler M, Smith RV, Wang B, Penner C, Theilken A Broughel $D$, et al. Validation of the histologic risk model in a new cohort of patients with head and neck squamous cell carcinoma. Am J Surg Pathol. 2010:34(5):677-88. 
11- Li Y, Bai S, Carroll W, Dayan D, Dort JC, Heller K, et al. Validation of the risk model: high-risk classification and tumor pattern of invasion predict outcome for patients with low-stage oral cavity squamous cell carcinoma. Head Neck Pathol. 2013:7(3):211-23.

12- Jardim JF, Francisco AL, Gondak R, Damascena A, Kowalski LP. Prognostic impact of perineural invasion and lymphovascular invasion in advanced stage oral squamous cell carcinoma. Int J Oral Maxillofac Surg. 2015:44(1):23-8.

13- Union for International Cancer Control - UICC. TNM Classification of Malignant Tumours. 8 $8^{\text {th }}$ ed. Geneva: UICC; 2017.

14- McShane LM, Altman DG, Sauerbrei W, Taube SE, Gion M, Clark GM. Reporting recommendations for tumour marker prognostic studies (REMARK). Br J Cancer. 2005:93(4):387-91.

15- Altman DG, McShane LM, Sauerbrei W, Taube SE. Reporting recommendations for tumor marker prognostic studies (REMARK): explanation and elaboration. BMC Medicine. 2012:10:51.

16- De Vicente JC, Lequerica-Fernández P, Santamaría J, Fresno MF. Expression of MMP-7 and MT1-MMP in oral squamous cell carcinoma as predictive indicator for tumor invasion and prognosis. J Oral Pathol Med. 2007:36(7):415-24.

17- Nóbrega TD, Queiroz SI, Santos EM, Costa AL, Pereira-Pinto L, Souza LB. Clinicopathological evaluation and survival of patients with squamous cell carcinoma of the tongue. Med Oral Patol Oral Cir Bucal. 2018;23(5):e579-87.

18- Honorato J, Camisasca DR, Silva LE, Dias FL, Faria PA, Lourenço SQ. Overall survival analysis in oral squamous cell carcinoma patients diagnosed at National Cancer Institute in 1999. Rev Bras Epidemiol. 2009:12(1): 69-81.

19- Myoung $\mathrm{H}$, Kim MJ, Lee JH, Ok YJ, Paeng JY, Yun PY. Correlation of proliferative markers (Ki-67 and PCNA) with survival and lymph node metastasis in oral squamous cell carcinoma: a clinical and histopathological analysis of 113 patients. Int J Oral Maxillofac Surg. 2006:35(11):1005-10.

20- Rodrigues PC, Miguel MC, Bagordakis E, Fonseca FP, Aquino SN, Santos-Silva AR, et al. Clinicopathological prognostic factors of oral tongue squamous cell carcinoma: a retrospective study of 202 cases. Int J Oral Maxillofac Surg. 2014:43(7):795-801.
21- Süslü N, Hoşal AŞ, Aslan T, Sözeri B, Dolgun A. Carcinoma of the oral tongue: a case series analysis of prognostic factors and surgical outcomes. J Oral Maxillofac Surg. 2013:71(7):1283-90

22- Fives C, Feeley L, O'Leary G, Sheahan P. Importance of lymphovascular invasion and invasive front on survival in floor of mouth cancer. Head Neck. 2016;Suppl 1:E1528-34.

23- Lwin CT, Hanlom R, Lowe D, Brown JS, Woolgar JA, Triantafyllou $A$, et al. Accuracy of MRI in prediction of tumour thickness and nodal stage in oral squamous cell carcinoma. Oral Oncol. 2012:48(2):149-54. 24- Camisasca DR, Honorato J, Bernardo V, Silva LE, Fonseca EC, Faria PA, et al. Expression of bcl-2 family proteins and associated clinicopathologic factors predict survival outcome in patients with oral squamous cell carcinoma. Oral Oncol. 2009:45(3):225-33.

25- Subramaniam N, Balasubramanian D, Murthy S, Kumar N, Vidhyadharan S, Vijayan SN, et al. Predictors of locoregional control in stage I/II oral squamous cell carcinoma classified by AJCC $8^{\text {th }}$ edition. Eur J Surg Oncol. Forthcoming 2019. doi.org/10.1016/j.ejso.2019.05.018. 26- Kurita $H$, Nakanishi $Y$, Nishizawa R, Xiao T, Kamata $T$, Koike T, et al. Impact of different surgical margin conditions on local recurrence of oral squamous cell carcinoma. Oral Oncol. 2010:46:814-7.

27- Amit M, Tam S, Takahashi H, Choi KY, Zafereo M, Bell D, et al. Prognostic performance of the American Joint Committee on Cancer $8^{\text {th }}$ edition of the TNM staging system in patients with early oral tongue cancer. Head Neck. 2018:1-7.

28- Sawazaki-Calone I, Rangel A, Bueno AG, Morais CF, Nagai HM, Kunz $\mathrm{RP}$, et al. The prognostic value of histopathological grading systems in oral squamous cell carcinomas. Oral Dis. 2015;21;755-61.

29- Boxberg M, Jesinghaus M, Dorfner C, Mogler C, Drecoll E, Warth $A$, et al. Tumour budding activity and cell nest size determine patient outcome in oral squamous cell carcinoma: proposal for an adjusted grading system. Histopathology. 2017;70(7):1125-37.

30- Lindenblatt RC, Martinez GL, Silva LE, Faria PS, Camisasca DR, Lourenço SQ. Oral squamous cell carcinoma grading systems analysis of the best survival predictor. J Oral Pathol Med. 2012:41(1):34-9. 31- Sopka DM, Tianyu LI, Lango MN, Mehra R, Liu CJ, Burtness B, et al. Dysplasia at the margin? Investigating the case for subsequent therapy in "Low-Risk" squamous cell carcinoma of the oral tongue. Oral Oncol. 2013:49(11):1083-7. 